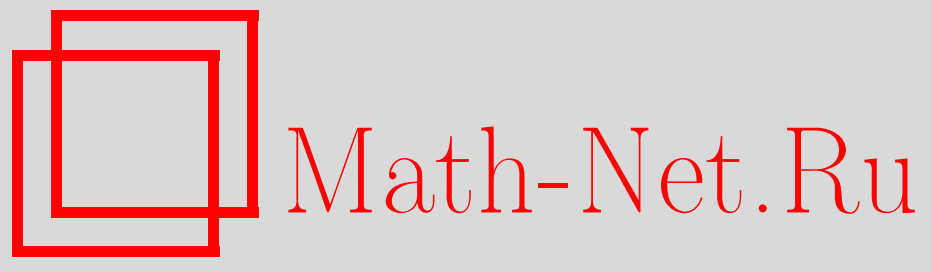

Памяти Владимира Игоревича Арнольда, УМН, 2010, том 65 , выпуск 3,3

DOI: https://doi.org/10.4213/rm9366

Использование Общероссийского математического портала Math-Net.Ru подразумевает, что вы прочитали и согласны с пользовательским соглашением http://www . mathnet.ru/rus/agreement

Параметры загрузки:

IP : 54.196 .121 .252

26 апреля 2023 г., 08:31:23 


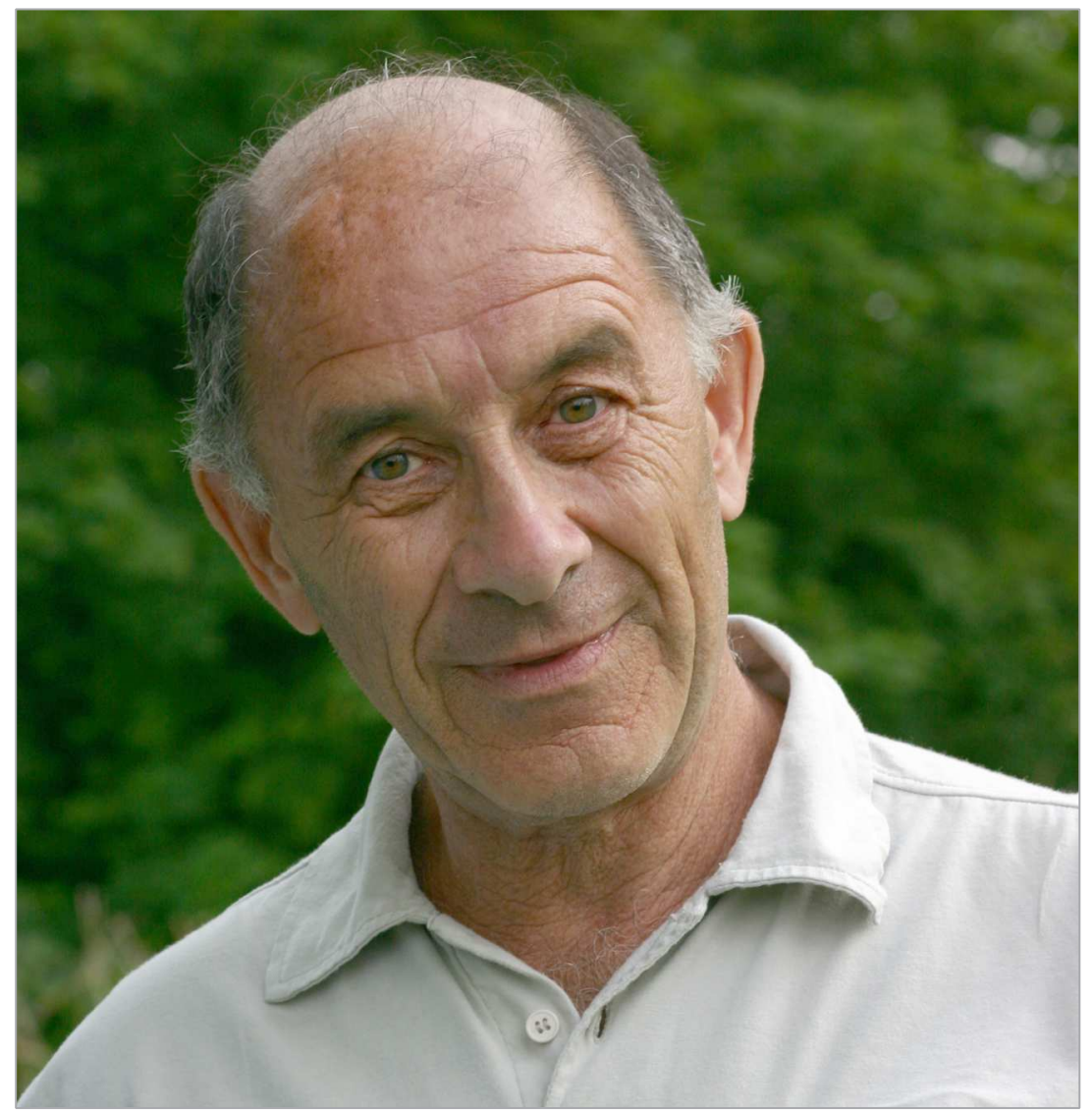

3 июня 2010 года скоропостижно ушел из жизни один из крупнейших математиков академик

\section{Владимир Игоревич Арнольд}

